\title{
Nutritional Quality and Mineral Content of Moringa oleifera Lam. Leaves Consumed in Guinea Savannah Vegetation Zones of Nigeria
}

\author{
Stanislaus Osuagwu Onyeberechiya \\ Department of Chemistry, Faculty of Science, Federal University of Lafia, Lafia, Nasarawa State, Nigeria \\ Email address: \\ osuagwu5050@yahoo.com

\section{To cite this article:} \\ Stanislaus Osuagwu Onyeberechiya. Nutritional Quality and Mineral Content of Moringa oleifera Lam. Leaves Consumed in Guinea \\ Savannah Vegetation Zones of Nigeria. Journal of Food and Nutrition Sciences. Vol. 9, No. 2, 2021, pp. 34-40. \\ doi: $10.11648 /$ j.jfns.20210902.11
}

Received: January 17, 2021; Accepted: January 25, 2021; Published: March 10, 2021

\begin{abstract}
Green leafy vegetables are good sources of food for they are rich in nutritional quality which plays significant physiological role in human body such as stimulating enzymes, antioxidants, reducing diseases such as diabetes, cardiac infarction, cancer and destroying bacteria including Salmonella species, Escherichia coli and Staphylococcus aureus. The aim of the study is to evaluate the nutritional quality and Mineral Content of Moringa oleifera Lam. leaves Consumed in Guinea Savannah Vegetation zones of Nigeria. Three fresh and powdered leaves of Moringa oleifera sample of $60 \mathrm{~g}$ each were randomly collected from three locations in Guinea Savannah Vegetation Zones via: Abuja (Gwagwalada market) in Southern Guinea Savannah; Katsina (Daura market) in Northern Guinea Savannah and Sokoto (Central market) in Sudan Guinea Savannah of Nigeria, and were analyzed for their nutritional quality and mineral content using standard analytical procedures. Each sample was determined in triplicates and data analyzed with SPSS version 16. The results revealed that Moringa oleifera Lam. leaves from various locations, are highly rich in macro and micro nutrients. The parameters varied in both locations, fresh and dried samples. The proximate composition results of Moringa oleifera Lam, leaves from various locations contain many nutritionally chemical compounds including Protein, Lipids, carbohydrate/sugars and fibers which are excellent functional food source for human and animal feedstock. Mineral element results revealed Moringa oleifera Lam. leaves from the guinea savannah of Nigeria, are rich in minerals and could be utilized as a cheap source of mineral supplements in human and animal diets. Potassium content ( $351.9 \pm 1.3 \mathrm{mg}$ to $367.0 \pm 1.4 \mathrm{mg} \mathrm{dwb})$ compared to Sodium values $(25.9 \pm 0.4-29.9 .9 \pm 0.5 \mathrm{mg}$, dwb) in the study, leads to a very low $\mathrm{Na} / \mathrm{K}$ ratio which is a favorable diet nutritionally, that is associated with lower incidence of hypertension. Calcium $(586.0 \pm 6.6 \mathrm{mg}$, dwb), is the most abundant mineral element recorded by Abuja sample, East of Gwagwalada market, while Zinc $(1.9 \pm 1.3 \mathrm{mg}$, dwb), obtained by Sokoto sample, North of Central market, is the least mineral element in the study. In conclusion, the nutritional quality and mineral contents of Moringa oleifeara Lam. leaves in the studied areas varied in locations, fresh and dried samples and contain an appreciable amount of macro and micro nutrients which are excellent functional food source for human and animal feedstock and can be explored for export as an international commodity.
\end{abstract}

Keywords: Nutritional Quality, Moringa oleifera, Mineral Content, Vegetables, Nigeria

\section{Introduction}

Green leafy vegetables are rich in vitamins, mineral elements, phytochemical compounds and antioxidants that the body needs to function effectively $[1,2]$. They are good source of food because of their riches in nutritional quality which include beta- carotene, ascorbic acid, minerals, fibers and essential oils which plays significant physiological role in human body as an antioxidant, stimulating enzymes, destroying bacteria and reducing diseases such as heart and cancer. The phytochemical compounds in green leafy vegetables possess antimicrobial properties and it include alkaloids, anthraquiones, flavonoids, phenols, tannins, terpenoids and saponins [3]. Internal system of antioxidants 
exists in human body to get rid of excessive free radicals from metabolism, but exogenous/natural antioxidant which green leafy vegetables can provide is needed [4].

The vegetables, including Moringa leaves, either fresh or dried, are available, accessible, and affordable at the least costs to every household, including the rich and the poor [1, 2]. Moringa oleifera Lam. leaves is consumed worldwide because of its nutritional quality including macro and micro nutrients, for medicinal purposes and industrial uses in water effluent treatments [5, 6, 7]. Different parts of Moringa oleifera Lam. plant are sources of proteins, vitamins, minerals and phytochemical compounds which exhibits pharmacological and biotechnological potentials. On the other hand, the leaves, flowers, pods and seeds of the plant are considered essential food source of high nutritional quality in developing countries such as Nigeria. Moringa oleifera Lam. leaves can be eaten cooked or fresh and can be stored dried for long period unrefrigerated without loss in nutrient quality. However, room/shade drying is the best processing method that preserves the nutritional quality of Moringa oleifera Lam. Leaves [1].

Moringa oleifera plant (Moringa or drumstick) is native to sub- Himalaya region of Northwest India. It is widely distributed throughout Africa, Southeast Asia, the Caribbean Islands and South America [8]. Health workers now treat malnutrition in small children and pregnant and nursing women with $M$. oleifera leave powder because of its nutrients. The iron content of the leave is very high and the powder is prescribed for the treatment of anemia in the Philippines [1, 2, 5, 6, 7, 9]. M. oleifera leaves contain phenolics and flavonoids compounds which exhibits various biological activity including antioxidants, anticarcinogenic, immunomodulatory, antidiabetes and the regulation of thyroid status [10]. Also, Moringa oleifera leaves is often the only source of protein, vitamins and minerals to the less privileged in the society and the leaves are used in the control of hypertension because the $\mathrm{Na} / \mathrm{K}$ ratio content of the leaves is low $[11,12]$.

Sun drying is a traditional method of preservation of agricultural produce including vegetables such as Moringa leaves, grains, seeds and fruits in Africa [13]. Although, this practice is carried out under poor unhygienic conditions, it confers on agricultural produce storage stability, reduces losses, makes food available for consumption during scarcity, inhibits the growth of food spoilage microorganisms including bacteria, viruses, fungi, and parasites $[1,14]$. The process is slow and takes much time to achieve the required food safety limit of food contaminants by World Health Organization [15]. Besides, the process is carried out in an opened poor unhygienic condition which enhances the increase of microbial contamination from the environment, human and animal activities [16, 17]. Among the drying methods: Room, Sun, Solar, Oven, Lyophilization, Commercial food dehydrator, [1], reported that room/shade drying is the best processing method that preserves the nutritional quality of Moringa oleifera Lam. leaves.
Moringa oleifera plant is abundant all over Nigeria, and the products serve multipurpose values to meet recent human challenges which include malnutrition, diseases, hunger, portable water, and employment $[1,2]$. The leaves are widely consumed in Nigeria, but the nutrient quality and mineral content of Moringa oleifera Lam. leaves consumed in guinea savannah zones of Nigeria, has hardly been documented, and that is what this study is set to unravel.

\section{Materials and Methods}

\subsection{Sampling}

Locally processed fresh and powdered leaves of Moringa oleifera were randomly collected from three locations in Guinea Savanna Vegetation Zones via: Abuja (Gwagwalada market) in Southern Guinea Savanna; Katsina (Daura market) in Northern Guinea Savanna, and Sokoto (Central market) in Sudan Guinea Savanna of Nigeria. Three fresh and powdered leave samples of approximately $60 \mathrm{~g}$ per market location (East, West and North) were collected aseptically into a sterile polythene zip bags for analysis.

\subsection{Analytical Methods}

Nutrient and elemental contents were determined according to the procedures of AOAC [18]. Each parameter was determined in triplicates and their mean values recorded.

\subsection{Determination of Nutrient Element Composition}

\subsubsection{Moisture Contents}

The water content was determined by the oven drying method [18]. Analysis was carried out in triplicates. A crucible was weighed empty $\left(\mathrm{W}_{0} \mathrm{~g}\right)$ using aeAdam analytical balance, model N17250. Thereafter, five grams $(5 \mathrm{~g})$ of samples were added into the dish and weighed $\left(\mathrm{W}_{1} \mathrm{~g}\right)$. Then the setup was placed in a drying oven, Genlab, model $\mathrm{MINO} / 50$, set at $105^{\circ} \mathrm{C}$ and heated for 5 hours. Thereafter, the crucibles and contents were allowed to cool in a desiccator for 45 minutes and were weighed. The process of heating and weighing were repeated till a constant mass $\left(\mathrm{W}_{3} \mathrm{~g}\right)$, was obtained. The ratio of loss in weight to weight of samples multiplied by 100 , gives the percentage of moisture content.

\subsubsection{Ash Content}

This was determined according to the Furnace ash method [18]. Assay was done in triplicates. Gallenkamp electric muffle furnace, model 3, was used. Clean and dried crucible was weighed empty $\left(\mathrm{W}_{\mathrm{o}} \mathrm{g}\right)$. Then, five grams sample was added into the crucible and weighed $\left(\mathrm{W}_{1} \mathrm{~g}\right)$. The setup was then put into the furnace and ashed at the temperature of $550^{\circ} \mathrm{C}$, for 5 hours. After cooling, the setup was weighed $\left(\mathrm{W}_{2} \mathrm{~g}\right)$. The ratio of $\mathrm{W}_{2} \mathrm{~g}$ minus $\mathrm{W}_{\mathrm{o}} \mathrm{g}$ to $\mathrm{W}_{1} \mathrm{~g}$ minus $\mathrm{W}_{\mathrm{o}} \mathrm{g}$, multiplied by 100 , gives the percentage ash content.

\subsubsection{Fat Content}

Soxhlet method of extraction using petroleum ether was 
adopted [18]. Five grams of sample was continuously extracted with petroleum ether for 6 hours till the liquid in the side arm Soxhlet apparatus was colorless. The residue in the round bottom flask after the solvent was evaporated represents the fat. The difference between the weight of flask and residue and the weight of flask empty, upon the weight of sample, multiplied by 100 , gives the percentage fat content.

\subsubsection{Crude Protein}

Kjeldahl [18], procedures were adopted for the determination of sample crude protein. Analyte was determined in triplicates. Five grams of sample was weighed into micro kjeldahl digestion flask. Then, $20 \mathrm{ml}$ of concentrated sulphuric acid $\left(\mathrm{H}_{2} \mathrm{SO}_{4}\right)$ was added with catalyst. The setup was mixed by shaking and later was digested by heating on an aluminum heating mantle in a fume cupboard, for 6 hours. Digestion was complete when the digested residue was grey colored. Flask and digest were allowed to cool at room temperature. Then, $30 \mathrm{ml}$ of distilled water was introduced to dissolve the residue. Quantitatively, the resulting solution was transferred into kjeldahl distillation apparatus where ammonia was liberated at the introduction of $40 \%$ sodium hydroxide solution. The liberated ammonia was trapped in a $50 \mathrm{ml}$ boric acid in $100 \mathrm{~mL}$ conical flask. The borate was titrated with $0.1 \mathrm{M}$ HCL standard solution. The calculated percentage Nitrogen $(\% \mathrm{~N})$ multiplied by 6.25 , gives the value of crude protein.

\subsubsection{Crude Fiber}

The crude fiber content was estimated by the insoluble formic method [19]. Five grams of sample was put in a vial containing $100 \mathrm{ml}$ of formic acid $(\mathrm{HCOOH}) 80 \%(\mathrm{~V} / \mathrm{V})$. The mixture was placed in the boiling water for 75 minutes, and cooled afterwards. The digested product was filtered and the insoluble phase was recovered in a crucible, dried at $103^{\circ} \mathrm{C}$ and weighed $\left(\mathrm{W}_{1} \mathrm{~g}\right)$. This was incinerated in an oven and the weight of the ashes were determined $\left(\mathrm{W}_{2} \mathrm{~g}\right)$. The crude fiber content was determined from the differences of these two weights.

\subsubsection{Total Sugar Content}

Tollier and Robin method was adopted [20]. Sample was analyzed in triplicate. Zero-point one gram of sample was weighed into a test tube containing $10 \mathrm{ml}$ of $\mathrm{NaOH}, 0.1 \mathrm{~N}$. The mixture was placed in boiling water for 30 minutes, and cooled. Thereafter, $0.01 \mathrm{ml}$ of the mixture was pipetted into three test tubes and the following were added: $0.99 \mathrm{ml}$ distilled water, $2 \mathrm{ml}$ arcinol solution and $7 \mathrm{ml}$ of $\mathrm{H}_{2} \mathrm{SO}_{4} 60 \%$. The mixture was homogenized and was placed again in hot water $\left(80^{\circ} \mathrm{C}\right.$; water bath) for 20 minutes and cooled thereafter for 45 minutes. The developed color was read in a UV visible spectrophotometer (T60, PG instrument, model T60U) at wave length 510 nanometer (nm). A curve of standardization was prepared using glucose $0.5 \mathrm{mg} / \mathrm{ml}$ as reference with the range of concentration in glucose varying between 5 and $50 \mathrm{mg} / \mathrm{ml}$. The curve helped to determine the concentration in total sugars of samples.

\subsubsection{Energizing Values}

The energizing values of proteins, total sugars, and lipids, were determined by Merrill and Watt coefficients adopted by the Food and Agriculture Organization in 1970 [21]. The energizing values of the samples were gotten by: P x 4 Kcal + $\mathrm{G} \times 4 \mathrm{Kcal}+\mathrm{L} \times 9 \mathrm{Kcal}=\mathrm{X} \mathrm{Kcal} / 100 \mathrm{~g}$. Where: $\mathrm{P}=$ Percentage of protein; $\mathrm{G}=$ Percentage of sugar; $\mathrm{L}=$ Percentage of lipids; $\mathrm{X}=$ Energizing values.

\subsection{Micronutrient Analysis}

Kjeldahl, procedures were adopted for the analysis. [18] Each parameter was analyzed in triplicate. Phosphorus (P), Potassium (K), Sodium (Na), Magnesium (Mg), Calcium (Ca), Iron (Fe), Zinc ( $\mathrm{Zn})$, Manganese (Mn), were determined in the samples after the mineralization [22]. Magnesium (Mg), Calcium (Ca), Iron (Fe), Zinc ( $\mathrm{Zn})$, Manganese (Mn), were determined using Atomic Absorption Spectrophotometer (PG AAS, model 990); Potassium (K) and Sodium (Na), were analyzed using Flame photometer (Jenway, model P7) and Phosphorus (P), was determined colorimetrically using the ammonium molybdate as indicator and read at wavelength of 880 nanometer $(\mathrm{nm})$ in a UV visible spectrophotometer (T60, PG instrument, model T60U). Ranges of standards were prepared for the analysis of concentration of micronutrients. Phosphorus (P), a stock standard solution of 30ppm of potassium hydrogen phosphate $\left(\mathrm{KHPO}_{4}\right)$, allows to prepare a concentration range between 3 and $15 \mathrm{ppm}$. Potassium $(\mathrm{K})$, and sodium $(\mathrm{Na})$; a stock standard solution of sodium and potassium 100ppm, allows to prepare a range concentration between 0 and $10 \mathrm{ppm}$. Magnesium (Mg), and calcium (Ca); stock standard solutions of magnesium (1000ppm) and calcium (1000ppm), allowed preparation concentrations range between 5 and $30 \mathrm{ppm}$ for calcium, 0.5 and $3 \mathrm{ppm}$ for magnesium. A standard concentration range of 6 and $36 \mathrm{ppm}$ for iron $(\mathrm{Fe})$, and 1 to $6 \mathrm{ppm}$ for zinc $(\mathrm{Zn})$, were prepared for the calibration of the linearity of Atomic Absorption Spectrophotometer for $\mathrm{Zn}$ and Fe analysis.

\subsection{Statistical Analysis}

The research experimental design was a factorial experiment fitted into a complete randomized design. Four treatments, three locations, two factors of three replicates each were involved. The data were subjected to statistical analyses to evaluate the differences between nutrient quality and mineral elements of samples. The data were analyzed with the SPSS version 16 for windows in a general linear model. The mean separation of data analyzed was done with the Duncan Multiple Range Test $\mathrm{P}<0.05$. The results were expressed as mean and standard error of mean. The difference was considered significant at $\mathrm{P}<0.05$.

\section{Results and Discussion}

\subsection{Macronutrients Analysis}

The assessment of proximate and nutrient quality of 
Moringa oleifera Lam. leaves, fresh and dried, is important in food security and safety programme. The mean values of the studied Moringa oleifera Lam. leaves, fresh and dried, from three different locations in the Savannah zones of Nigeria, is presented in Table 1. There is statistical significance $(\mathrm{P}<0.05)$ among the mean values of parameters assayed. Moisture, Protein, Fat, Fiber, Ash, Total sugar/Carbohydrate and Energy contents varied significantly $(\mathrm{P}<0.05)$ between fresh and dried Moringa oleifera leaves investigated (Table 1).

Obtained mean values of Moringa oleifera powdered dried leaves in $\mathrm{g} / 100 \mathrm{~g}$ dried weight basis $(\mathrm{g} / 100 \mathrm{~g}$, dwb) showed that the maximum moisture content $(9.6 \pm 03 \%)$ was from Abuja sample, East of Gwagwalada market, minimum moisture $(6.8 \pm 0.26 \%)$ was from Sokoto sample, North of central market; highest Protein result (27.25 $\pm 1.0 \%$ ), Sokoto sample, North of central market, lowest Protein result $(24.5 \pm 0.9 \%)$, Abuja sample, North of Gwagwalada market; maximum Fat result $(4.0 \pm 0.5 \%)$, Katsina sample, East of Daura market, minimum fat value $(1.25 \pm 0.1 \%)$, Sokoto sample, East of central market; highest Fiber value $(14.0 \pm 0.5 \%)$, Katsina sample, East of Daura market, lowest fiber result $(11.6 \pm 0.4 \%)$, Katsina sample, North of Daura market; maximum Ash content $(9.0 \pm 0.3 \%)$, Katsina sample, East of Daura market, minimum ash content $(6.65 \pm 0.3 \%)$, Abuja sample, North of Gwagwalada market; highest total sugar result $(36.0 \pm 1.4 \%)$, Katsina sample, East of Daura market, lowest total sugar result $(27.56 \pm 1.0 \%)$, Sokoto sample, West of central market; Energy maximum mean value (295.0 $\pm 3.4 \mathrm{Kcal})$, Katsina sample, west of Daura market and minimum energy result $(265.6 \pm 3.1 \mathrm{Kcal})$, Sokoto sample, East of central market (Table 1).

Nonetheless, the recorded mean values of this investigation are in agreement with the values documented by Joshi and Mehta, who reported Protein 24.42\%, Fiber $11.3 \%$, Energy $268.56 \mathrm{Kcal}$, Carbohydrate $27.98 \%$, Moisture $6.0 \%$ and Ash 7.6\% [5]; also, the recorded mean values agreed with the following reported values: protein $30.3 \%$, fat $6.5 \%$, Ash 7.6\%, Moisture 9.5\% from Moringa leaves, South Africa ecotype; $\left[{ }^{6]}\right.$ moisture $6.9 \%$, protein $22.5 \%$, fat $3.1 \%$, Ash $7.1 \%$, fiber $10.8 \%$, energy $244.1 \mathrm{Kcal}$, from Moringa leaves grown in savannah Nigeria [1]; but is lower than the results of Protein 29.54\%, Fat 7.56\%, Ash 17.26\% from Rwanda sample and Ash $13.42 \%$ from China sample; [7] moisture $7.4 \pm 2.9 \%$, fiber $9.46 \pm 1.14 \%$, Ash $10.71 \pm 0.81$ $17.6 \%$, protein $10.74 \pm 1.3$ - $24 \pm 5.8 \%$, energy $304 \pm 87$ $366.2 \pm 4.23 \mathrm{Kcal}$ from Mexico samples [2].

The variations in mean values of studied samples and cited Literatures could be ascribed to differences in soil factor, Cultivar of plants, genetic background, season, increases in concentration in dehydrated leaves, geographical locations and analytical procedures employed.

However, health workers now treat malnutrition in small children, pregnant and nursing women with $M$. oleifera leave powder, because of its nutritional quality including Protein. The mean protein content recorded in this study ranged from $24.5 \pm 0.9 \%$ to $27.25 \pm 1.0 \%$, dwb (Table 1 ), is within the range of $16-65 \mathrm{mg} / \mathrm{l}$ recommended dietary allowances (RDAs) in
Children and lactating women. [23] This indicates that Moringa oleifera, leaves from the three different locations are rich in protein and can serve as an excellent food source for human and animal nutrition. Sokoto sample recorded the highest protein mean value of $27.25 \pm 1.0 \%$, followed by Gwagwalada sample of mean value $24.5 \pm 0.9 \%$, dwb. Fat mean value $(1.25 \pm 0.5 \%$ to $4.0 \pm 0.5 \%)$ recorded in this study is in consonance with green leafy vegetables which are heart friendly food. On the other hand, the studied samples were rich in fiber, indicating that vegetables are a natural broom for the body. The ash value of this study ranges from $2.15 \pm 0.1 \%$ to $3.65 \pm 0.1 \%$ of fresh weight or $6.65 \pm 0.3 \%$ to $9.0 \pm 03 \%$ of dried weight basis, indicating that the leaves are rich in inorganic minerals including $\mathrm{Ca}, \mathrm{K}, \mathrm{Mg}, \mathrm{Zn}, \mathrm{Fe}, \mathrm{Na}$, which can be used as a source of food to overcome malnutrition in children and infants in developing countries of the world. The sugars are the main source of energy and the mean range values of this investigation varies from $13.85 \pm 0.5 \%$ to $15.6 \pm 0.6 \%$ of fresh weight, or $27.56 \pm 1.0 \%$ to $36.0 \pm 1.4 \%$ of dried weight basis (Table 1), indicating that dried powdered Moringa leaf contain low calorific value which can be used in the diet of the obese.

The proximate composition values of the investigated Moringa oleifera Lam, leaves from various locations contain many nutritionally chemical compounds including Protein, Lipids, carbohydrate/sugars and fibers which are excellent functional food source for human and animal feedstock.

\subsection{Micronutrient Analysis}

The mean values of micronutrient elements of fresh and dried leaves of Moringa oleifera Lam. leaves investigated from three various locations is presented in Table 2. There are statistical differences $(\mathrm{P}<0.05)$ among the mean values of studied parameters (Table 2). These variations could be due to soil factor, cultivars of plants, increases in concentration in dehydrated leaves or geographical locations with reference to different ecological vegetation zones (Northern, Southern and Sudan Guinea Savannah Vegetations).

However, the obtained mean values of parameters revealed high content of Calcium (Ca) $678.6 \pm 7.6 \mathrm{mg}$ to $695.0 \pm 6.6 \mathrm{mg}$ of fresh weight (fw) or $556.8 \pm 6.2 \mathrm{mg}$ to $586.0 \pm 6.6 \mathrm{mg}$ of dried weight basis (dwb). Katsina sample, North of Daura market, recorded the lowest Calcium value of $556.8 \pm 6.2 \mathrm{mg}$ and Abuja sample, East of Gwagwalada market, reported the highest Calcium value of $586.0 \pm 6.6 \mathrm{mg} \mathrm{dwb}$ (Table 2). These results are lower than the values of $2098.1 \mathrm{mg}$ from Burkina Faso; [24] $3283 \mathrm{mg}$, reported by Joshi and Mehta; [5] 2951 $\mathrm{mg}$ from Thailand; [25] 4168-4283mg from guinea savanna Nigeria; [1] 1897 \pm 748.4 - 2620.5 $\pm 5.6 \mathrm{mg}$ from Mexico. [2] But it is higher than the value of $3.65 \mathrm{mg}$ from South Africa, ecotype. [6] Variations in mean values could be due to soil factor, genetic background, cultivars of plant, analytical procedures and geographical locations. Nonetheless, the level of calcium $(556.8 \pm 6.2 \mathrm{mg}$ to $586.0 \pm 6.6 \mathrm{mg}$, dwb) in the studied samples, is adequate and within the required needs of the body for its biological activities. [26, 27] However, 
Calcium plays a fundamental role in the constitution of biological systems; its presence in bones provides an animal with the required rigidity and support. $\left[{ }^{27]}\right.$ For pregnant women and breast-feeding women, consuming Moringa leaves is advised as they could do much to improve upon the mother's health and pass on nutrients to the foetus or nursing child. [27]

Similarly, Potassium (K) results varied between $320.8 \pm 1.2 \mathrm{mg}$ to $323.6 \pm 1.2 \mathrm{mg}$ (fw) or $351.9 \pm 1.3 \mathrm{mg}$ to $367.0 \pm 1.4 \mathrm{mg}$ (dwb) (Table 2). Katsina sample, North of Daura market, reported the minimum K result of $351.9 \pm 1.3$ $\mathrm{mg}$, and Sokoto sample, North of Central market, recorded the maximum $\mathrm{K}$ mean value of $367.0 \pm 1.4 \mathrm{mg}$ (dwb) (Table 2). The recorded result is lower than the value of $2054.1 \mathrm{mg}$ from Thailand. [25] $1922 \mathrm{mg}$ from Pakistan; [24] 2208-2312 $\mathrm{mg}$ from Moringa leaves grown in savannah Nigeria; [1] $1467 \pm 636.7-1845 \pm 7.0 \mathrm{mg}$ from Mexico samples. [2] However, it is higher than the value of $1.5 \mathrm{mg}$ from Moringa leaves. [6] The differences in mean values could be ascribed to increases in concentration in dehydrated leaves, soil factor, season, or geographical locations. However, Potassium exists primarily as an intracellular constituent in the body and its level in this study $(351.9 \pm 1.3 \mathrm{mg}$ to $367.0 \pm 1.4 \mathrm{mg}$, dwb) is within the level the body requires to maintain its biological activities for healthy conditions of an individual. [26] Accordingly, the content of Potassium compared to Sodium values $(25.9 \pm 0.4-29.9 .9 \pm 0.5 \mathrm{mg}, \mathrm{dwb})$ in this study, leads to a very low $\mathrm{Na} / \mathrm{K}$ ratio which is a favorable diet nutritionally, that is associated with lower incidence of hypertension. [11]

On the other hand, Phosphorus (P) mean results varied from $285.8 \pm 3.3 \mathrm{mg}$ to $295.6 \pm 3.4 \mathrm{mg}$ (dwb) (Table 2). Abuja sample, West of Gwagwalada market, recorded the minimum $\mathrm{P}$ mean value of $285.3 \pm 3.3 \mathrm{mg}(\mathrm{dwb})$, while the maximum $\mathrm{P}$ mean value of $295.6 \pm 3.4 \mathrm{mg}$ (dwb), was obtained by Sokoto sample, North of Central market (Table 2). The analyzed results are higher than these values $(35.1 \mathrm{mg} ; 0.3 \mathrm{mg} ; 203.0$ $\mathrm{mg} ; 259.0 \mathrm{mg}$ ). [24, 6, 5, 1] Accordingly, Phosphorus is involved in the synthesis of Protein and Amino acids in the body, and the recorded level $(250-268 \mathrm{mg})$, in this study, is within the body requirement for these functions. [26, 27]

Also, Magnesium $(\mathrm{Mg})$ and Iron $(\mathrm{Fe})$ mean results in this study varied thus: $\mathrm{Mg}(280.6 \pm 2.3 \mathrm{mg}$ to $368.6 \pm 3.0 \mathrm{mg}$, dwb) and $\mathrm{Fe}(30.8 \pm 2.6 \mathrm{mg}$ to $36.8 \pm 2.8 \mathrm{mg}$, dwb) (Table 2). Abuja sample, East of Gwagwalada market, recorded the minimum $\mathrm{Mg}$ value of $280.6 \pm 2.3 \mathrm{mg}$ (dwb), while the maximum $\mathrm{Mg}$ mean value of $368.6 \pm 3.0 \mathrm{mg}$ (dwb), was obtained by Katsina sample, North of Daura market. Again, Katsina sample, East of Daura market, reported the minimum iron value of $30.8 \pm 2.4 \mathrm{mg}$, while the maximum iron value of $36.8 \pm 2.8 \mathrm{mg}$ (dwb) was from Sokoto sample, East of Central market (Table 2). The obtained $\mathrm{Mg}$ results of this study is lower than the values (406.0 $\mathrm{mg}$ and $378 \mathrm{mg}$ ) of Moringa from Burkina Faso and Guinea Savannah of Nigeria respectively. [24, 1] Similarly, the obtained iron values are lower than the values (37.6 $\mathrm{mg}$ and $38.3 \mathrm{mg}$ ) obtained from Thailand and Pakistan $[25,24]$. Respectively, but is higher than the values $(25.8 \mathrm{mg}$ and $24 \mathrm{mg}$ ) reported of Moringa leaves and that from Guinea
Savannah of Nigeria, respectively. [6, 1]. Soil factor, Plant cultivars, and geographical locations could be ascribed to variations in values. Scientifically, $\mathrm{Mg}$ and $\mathrm{Fe}$, are important in the formation of hemoglobin in the body, and the recorded levels for $\mathrm{Fe}$ : $(30.8 \pm 2.4 \mathrm{mg}-36.8 \pm 2.8 \mathrm{mg})$ and $\mathrm{Mg}$ : $(280.6 \pm 2.3 \mathrm{mg}$ to $368.6 \pm 3.0 \mathrm{mg}$ ), in this study, are adequate and within the range for the formation of hemoglobin building in the body [28, 27]. Accordingly, the high amount of $\mathrm{Mg}$ and $\mathrm{Fe}$, recorded in this study, suggests that Moringa oleifera leaves could be a good source for dietary $\mathrm{Mg}$ and $\mathrm{Fe}$, to overcome $\mathrm{Mg}$, and $\mathrm{Fe}$, diseases and nutritional deficiency if supplemented in diet, knowing that $\mathrm{Mg}$, intake has been implicated in prevention of cardiovascular disease, insulin sensitivity and diabetes.

Also, Manganese $(\mathrm{Mn})$ and Zinc $(\mathrm{Zn})$, varied thus: $\mathrm{Mn}$ (2.8 $\pm 1.1 \mathrm{mg}$ to $3.8 \pm 1.4 \mathrm{mg}, \mathrm{dwb})$ and $\mathrm{Zn}(1.3 \pm 0.9 \mathrm{mg}$ to $1.9 \pm 1.3 \mathrm{mg}$, dwb) (Table 2). Katsina sample, East of Daura market, and Sokoto sample, North of Central market, each recorded the lower $\mathrm{Mn}$ value of $2.8 \pm 1.1 \mathrm{mg}$ and Abuja sample, West of Gwagwalada market, recorded the higher Mn value of $3.8 \pm 1.4 \mathrm{mg} \mathrm{dwb}$; again, Katsina sample, East of Daura market documented the minimum $\mathrm{Zn}$ result of $1.3 \pm 0.9$ $\mathrm{mg}$ and Sokoto sample, East and North of Central market recorded the maximum $\mathrm{Zn}$ value of $1.9 \pm 1.3 \mathrm{mg}$ dwb (Table 2). However, the obtained $\mathrm{Zn}$ results are lower than the values $(5.4 \mathrm{mg}, 13.03 \mathrm{mg}$ and $1.0 \pm 0.7-2.4 \pm 1.12 \mathrm{mg}$ ) of Moringa oleifera Lam. leaves from Burkina Faso, South Africa ecotype and Mexico respectively, [24, 6, 2] but is higher than the value of 1.1-1.50 mg from Guinea Savannah Vegetation Zones of Nigeria. [1] Differences in mean values could be associated with the increases in concentration in dehydrated leaves, soil factor or geographical locations. Mn acts as activator of many enzymes, and its level in this study $(2.8 \pm 1.1 \mathrm{mg}$ to $3.8 \pm 1.4 \mathrm{mg})$ is within the body need for this function. [26] $\mathrm{Zn}$ on the other hand, is involved in normal function of the immune system, synthesis of RNA, DNA, reproduction of cells including sperm cells, possesses antiviral, antibacterial, and antifungal properties, and the obtained value $(1.3 \pm 0.9 \mathrm{mg}$ to $1.9 \pm 1.3 \mathrm{mg}$, dwb) in this investigation is adequate for these functions. [26, 28]

In this study, the abundance of mineral elements in relation to locations is in this descending order: most abundant, Calcium $(586.0 \pm 6.6 \mathrm{mg}$, dwb) is recorded by Abuja sample, East of Gwagwalada market; Potassium (367.0 $1.4 \mathrm{mg}$, dwb) documented by Sokoto sample, North of Central market; Magnesium (368.6 $\pm 3.0 \mathrm{mg}, \mathrm{dwb}$ ) obtained by Katsina sample, North of Daura market; Phosphorus (295.6 $\pm 3.4 \mathrm{mg}$, $\mathrm{dwb})$ reported by Sokoto sample, North of Central market; Iron (36.8 $\pm 2.8 \mathrm{mg}, \mathrm{dwb})$ obtained by Sokoto sample, East of Central market; Sodium (29.9.9 $\pm 0.5 \mathrm{mg}$, dwb) recorded by Sokoto sample, West of Central market; Manganese (3.8 \pm 1.4 mg, dwb) obtained by Abuja sample, West of Gwagwalada market and Zinc $(1.9 \pm 1.3 \mathrm{mg}$, dwb) obtained by Sokoto sample, North of Central market (Table 2). The results of elemental analysis of this investigation revealed that Moringa oleifera Lam. leaves from the guinea savannah of Nigeria, are rich in minerals and could be utilized as a cheap source of 
mineral supplements in human and animal diets.

Table 1. Proximate Composition of Moringa oleifera Lam. Leaves at Various Locations (g/100g DWB).

\begin{tabular}{|c|c|c|c|c|c|c|c|c|}
\hline \multirow{2}{*}{ Locations } & \multirow{2}{*}{ Samples } & \multicolumn{7}{|c|}{ Nutrients (\%) } \\
\hline & & Moisture\% & Protein $\%$ & Fat \% & Fiber \% & Ash \% & Total sugar $\%$ & Energy (Kcal) \\
\hline \multirow{4}{*}{$\begin{array}{l}\text { Abuja. (Gwagwalada } \\
\text { market). }\end{array}$} & Fresh & $74.8 \pm 0.9^{\mathrm{a}}$ & $7.7 \pm 0.3^{\mathrm{d}}$ & $1.8 \pm 0.2^{\mathrm{d}}$ & $1.6 \pm 0.1^{\mathrm{d}}$ & $3.7 \pm 0.1^{\mathrm{d}}$ & $15.6 \pm 0.6^{\mathrm{a}}$ & $88.9 \pm 1.0^{\mathrm{c}}$ \\
\hline & Dried leaves, East of market. & $9.6 \pm 0.4^{b}$ & $26.6 \pm 1.0^{\mathrm{a}}$ & $2.9 \pm 0.3^{\mathrm{c}}$ & $13.7 \pm 0.5^{\mathrm{a}}$ & $8.0 \pm 0.3^{\mathrm{a}}$ & $35.6 \pm 1.4^{\mathrm{a}}$ & $284.6 \pm 3.3^{\mathrm{b}}$ \\
\hline & Dried leaves, West of market. & $7.4 \pm 0.3^{\mathrm{c}}$ & $25.8 \pm 1.0^{\mathrm{b}}$ & $3.0 \pm 0.4^{\mathrm{b}}$ & $12.0 \pm 0.5^{\mathrm{c}}$ & $7.3 \pm 0.3^{\mathrm{b}}$ & $30.7 \pm 1.2^{\mathrm{c}}$ & $290.7 \pm 3.4^{\mathrm{a}}$ \\
\hline & Dried leaves, North of market. & $7.0 \pm 0.3^{c}$ & $24.5 \pm 0.9^{c}$ & $3.1 \pm 0.4^{\mathrm{a}}$ & $13.2 \pm 0.5^{\mathrm{b}}$ & $6.6 \pm 0.3^{c}$ & $32.8 \pm 1.2^{\mathrm{b}}$ & $282.6 \pm 3.3^{b}$ \\
\hline \multirow{4}{*}{ Katsina. (Daura market). } & Fresh. & $72.6 \pm 0.8^{b}$ & $7.6 \pm 0.3^{\mathrm{c}}$ & $1.8 \pm 0.2^{\mathrm{d}}$ & $1.7 \pm 0.1^{\mathrm{d}}$ & $2.6 \pm 0.1^{\mathrm{d}}$ & $14.0 \pm 0.5^{\mathrm{d}}$ & $99.8 \pm 1.2^{\mathrm{c}}$ \\
\hline & Dried leaves, East of market. & $8.9 \pm 0.3^{\mathrm{b}}$ & $25.6 \pm 1.0^{\mathrm{b}}$ & $4.0 \pm 0.5^{\mathrm{a}}$ & $14.0 \pm 0.5^{\mathrm{a}}$ & $9.0 \pm 0.3^{\mathrm{a}}$ & $36.0 \pm 1.4^{\mathrm{a}}$ & $294.0 \pm 3.4^{\mathrm{a}}$ \\
\hline & Dried leaves, West of market. & $7.1 \pm 0.3^{\mathrm{c}}$ & $25.7 \pm 1.0^{\mathrm{b}}$ & $3.2 \pm 0.4^{\mathrm{b}}$ & $13.2 \pm 0.5^{\mathrm{b}}$ & $8.9 \pm 0.3^{\mathrm{b}}$ & $34.3 \pm 1.2^{\mathrm{b}}$ & $295.0 \pm 3.4^{\mathrm{a}}$ \\
\hline & Dried leaves, North of market. & $7.0 \pm 0.3^{\mathrm{c}}$ & $26.7 \pm 1.0^{\mathrm{a}}$ & $2.5 \pm 0.3^{\mathrm{c}}$ & $11.6 \pm 0.4^{\mathrm{c}}$ & $7.7 \pm 0.3^{c}$ & $30.7 \pm 1.2^{\mathrm{c}}$ & $290.3 \pm 3.4^{\mathrm{b}}$ \\
\hline \multirow{4}{*}{ Sokoto. (Central market). } & Fresh & $76.9 \pm 0.9^{\mathrm{a}}$ & $7.8 \pm 0.3^{\mathrm{b}}$ & $1.9 \pm 0.2^{\mathrm{d}}$ & $1.3 \pm 0.1^{\mathrm{d}}$ & $2.2 \pm 0.1^{\mathrm{c}}$ & $13.9 \pm 0.5^{\mathrm{d}}$ & $96.8 \pm 1.2^{\mathrm{d}}$ \\
\hline & Dried leaves, East of market. & $7.6 \pm 0.3^{\mathrm{b}}$ & $27.1 \pm 1.0^{\mathrm{a}}$ & $1.3 \pm 0.1^{\mathrm{b}}$ & $13.7 \pm 0.5^{\mathrm{b}}$ & $7.8 \pm 0.3^{\mathrm{a}}$ & $29.4 \pm 1.1^{\mathrm{b}}$ & $265.6 \pm 3.1^{\mathrm{c}}$ \\
\hline & Dried leaves, West of market. & $7.3 \pm 0.3^{\mathrm{c}}$ & $27.2 \pm 1.0^{\mathrm{a}}$ & $3.5 \pm 0.4^{\mathrm{a}}$ & $14.0 \pm 0.5^{\mathrm{a}}$ & $6.8 \pm 0.3^{\mathrm{b}}$ & $27.6 \pm 1.0^{\mathrm{c}}$ & $268.7 \pm 3.1 \mathrm{a}$ \\
\hline & Dried leaves, North of market. & $6.8 \pm 0.3^{\mathrm{d}}$ & $27.3 \pm 1.0^{\mathrm{a}}$ & $2.6 \pm 0.3^{\mathrm{d}}$ & $12.1 \pm 0.5^{\mathrm{c}}$ & $7.8 \pm 0.3^{\mathrm{a}}$ & $30.6 \pm 1.2^{\mathrm{a}}$ & $266.9 \pm 3.1 \mathrm{a}$ \\
\hline
\end{tabular}

Key: a-d Means in the same column but with different superscripts differ significantly $(\mathrm{P}<0.05)$.

$\pm \mathrm{SEM}=$ Standard Error Mean.

Values are means of three (3) determinations.

Table 2. Mineral Composition of Dried Moringa oleifera leaf (Mg/100g leaf powder) at Various Locations.

\begin{tabular}{|c|c|c|c|c|c|c|c|c|c|}
\hline \multirow{2}{*}{ Locations } & \multirow{2}{*}{ Samples (Mg) } & \multicolumn{8}{|c|}{ Nutrients (Mg/100g DWB) } \\
\hline & & Ca & $\mathbf{K}$ & $\mathrm{Na}$ & $\mathbf{P}$ & Mg & $\mathbf{F e}$ & Mn & $\mathbf{Z n}$ \\
\hline \multirow{4}{*}{$\begin{array}{l}\text { Abuja (Gwagwalada } \\
\text { market). }\end{array}$} & Fresh (mg) & $695.0 \pm 7.8^{\mathrm{a}}$ & $323.6 \pm 1.2^{\mathrm{d}}$ & $35.6 \pm 0.6^{\mathrm{d}}$ & $45.0 \pm 0.5^{\mathrm{d}}$ & $46.8 \pm 0.4^{\mathrm{d}}$ & $10.9 \pm 0.8^{\mathrm{c}}$ & $1.9 \pm 0.7^{\mathrm{d}}$ & $0.15 \pm 0.1^{\mathrm{d}}$ \\
\hline & Powdered leaf, East of market. & $586.0 \pm 6.6^{\mathrm{b}}$ & $365.5 \pm 1.4^{\mathrm{b}}$ & $29.7 \pm 0.5^{b}$ & $286.3 \pm 3.3^{\mathrm{b}}$ & $280.6 \pm 2.3^{c}$ & $33.8 \pm 2.6^{\mathrm{b}}$ & $3.5 \pm 1.3^{\mathrm{b}}$ & $1.5 \pm 1.1^{\mathrm{c}}$ \\
\hline & Powdered leaf, West of market & $577.2 \pm 6.5^{\mathrm{c}}$ & $364.2 \pm 1.4^{\mathrm{c}}$ & $26.8 \pm 0.5^{\mathrm{c}}$ & $285.8 \pm 3.3^{\mathrm{c}}$ & $282.7 \pm 2.3^{\mathrm{b}}$ & $34.0 \pm 2.6^{\mathrm{a}}$ & $3.8 \pm 1.4^{\mathrm{a}}$ & $1.7 \pm 1.2^{\mathrm{b}}$ \\
\hline & Powdered leaf, North of market. & $568.2 \pm 6.4^{\mathrm{d}}$ & $366.0 \pm 1.4^{\mathrm{a}}$ & $25.9 \pm 0.4^{\mathrm{d}}$ & $288.7 \pm 3.3^{\mathrm{a}}$ & $283.7 \pm 2.3^{\mathrm{a}}$ & $33.8 \pm 2.6^{\mathrm{b}}$ & $2.95 \pm 1.1^{\mathrm{c}}$ & $1.9 \pm 1.3^{\mathrm{a}}$ \\
\hline \multirow{4}{*}{$\begin{array}{l}\text { Katsina (Daura } \\
\text { market). }\end{array}$} & Fresh $(\mathrm{mg})$ & $678.6 \pm 7.6^{\mathrm{a}}$ & $320.8 \pm 1.2^{\mathrm{d}}$ & $34.7 \pm 0.6^{\mathrm{a}}$ & $44.2 \pm 0.5^{\mathrm{d}}$ & $47.6 \pm 0.4^{\mathrm{d}}$ & $11.8 \pm 0.9^{\mathrm{d}}$ & $1.6 \pm 0.6^{\mathrm{d}}$ & $0.2 \pm 0.1^{\mathrm{d}}$ \\
\hline & Powdered leaf, East of market. & $567.6 \pm 6.4^{\mathrm{c}}$ & $356.8 \pm 1.4^{\mathrm{a}}$ & $28.8 \pm 0.5^{\mathrm{c}}$ & $290.7 \pm 3.4^{\mathrm{c}}$ & $360.0 \pm 3.0^{\mathrm{c}}$ & $30.8 \pm 2.4^{\mathrm{c}}$ & $2.8 \pm 1.1^{\mathrm{c}}$ & $1.3 \pm 0.9^{\mathrm{c}}$ \\
\hline & Powdered leaf, west of market. & $578.7 \pm 6.5^{\mathrm{b}}$ & $355.9 \pm 1.4^{\mathrm{b}}$ & $29.0 \pm 0.5^{\mathrm{b}}$ & $293.3 \pm 3.4^{\mathrm{a}}$ & $366.7 \pm 3.0^{\mathrm{b}}$ & $34.9 \pm 2.7^{\mathrm{a}}$ & $2.9 \pm 1.1^{\mathrm{b}}$ & $1.4 \pm 1.0^{\mathrm{b}}$ \\
\hline & Powdered leaf, North of market. & $556.8 \pm 6.2^{\mathrm{d}}$ & $351.9 \pm 1.3^{\mathrm{c}}$ & $26.7 \pm 0.5^{\mathrm{d}}$ & $291.6 \pm 3.4^{\mathrm{b}}$ & $368.8 \pm 3.0^{\mathrm{c}}$ & $32.8 \pm 2.5^{\mathrm{b}}$ & $3.6 \pm 1.4^{\mathrm{a}}$ & $1.5 \pm 1.1^{\mathrm{a}}$ \\
\hline \multirow{4}{*}{$\begin{array}{l}\text { Sokoto (Central } \\
\text { market). }\end{array}$} & Fresh $(\mathrm{mg})$ & $685.8 \pm 7.7^{\mathrm{a}}$ & $320.8 \pm 1.2^{\mathrm{d}}$ & $34.9 \pm 0.6^{\mathrm{a}}$ & $42.6 \pm 0.4^{\mathrm{d}}$ & $45.8 \pm 0.4^{\mathrm{d}}$ & $12.8 \pm 1.0^{\mathrm{d}}$ & $1.7 \pm 0.6^{\mathrm{d}}$ & $0.3 \pm 0.2^{\mathrm{c}}$ \\
\hline & Powdered leaf, East of market & $566.8 \pm 6.4^{\mathrm{d}}$ & $366.8 \pm 1.4^{\mathrm{b}}$ & $27.8 \pm 0.5^{\mathrm{c}}$ & $292.6 \pm 3.4^{\mathrm{b}}$ & $350.8 \pm 3.0^{\mathrm{c}}$ & $36.8 \pm 2.8^{\mathrm{a}}$ & $2.9 \pm 1.1^{\mathrm{b}}$ & $1.9 \pm 1.3^{\mathrm{a}}$ \\
\hline & Powdered leaf, west of market. & $576.7 \pm 6.5^{\mathrm{b}}$ & $365.9 \pm 1.4^{\mathrm{c}}$ & $29.9 \pm 0.5^{\mathrm{b}}$ & $291.8 \pm 3.4^{\mathrm{c}}$ & $352.8 \pm 3.0^{\mathrm{b}}$ & $34.6 \pm 2.7^{b}$ & $3.0 \pm 1.1^{\mathrm{a}}$ & $1.8 \pm 1.3^{\mathrm{b}}$ \\
\hline & Powdered leaf, North of market. & $569.8 \pm 6.4^{\mathrm{c}}$ & $367.0 \pm 1.4^{\mathrm{a}}$ & $26.9 \pm 0.5^{\mathrm{d}}$ & $395.6 \pm 3.4^{\mathrm{a}}$ & $353.6 \pm 3.0^{\mathrm{a}}$ & $33.8 \pm 2.6^{\mathrm{c}}$ & $2.8 \pm 1.1^{\mathrm{c}}$ & $1.9 \pm 1.3^{\mathrm{a}}$ \\
\hline
\end{tabular}

Key: a-d means in the same column but with different superscripts differ significantly $(\mathrm{P}<0.05)$

$\pm \mathrm{SEM}=$ Standard Error Mean.

Values are means of three (3) determinations.

\section{Conclusion}

The results of the study revealed that Moringa oleifera Lam. leaves consumed in Guinea Savannah Vegetation zones of Nigeria, is highly rich in macro and micro nutrients. The investigated parameters varied in both locations, fresh and dried samples. The proximate composition results of investigated Moringa oleifera Lam, leaves from various locations contain many nutritionally chemical compounds including Protein, Lipids, carbohydrate/sugars and fibers which are excellent functional food source for human and animal feedstock. Similarly, the elemental analysis results of this study revealed that Moringa oleifera Lam. leaves from the guinea savannah of Nigeria, are rich in minerals and could be utilized as a cheap source of mineral supplements in human and animal diets. In addition, the content of Potassium ( $351.9 \pm 1.3 \mathrm{mg}$ to $367.0 \pm 1.4 \mathrm{mg} \mathrm{dwb}$ ) compared to Sodium values $(25.9 \pm 0.4-29.9 .9 \pm 0.5 \mathrm{mg}, \mathrm{dwb})$ in this study, leads to a very low $\mathrm{Na} / \mathrm{K}$ ratio which is a favorable diet nutritionally, that is associated with lower incidence of hypertension. In the study, the abundance of mineral elements in relation to locations is in the descending

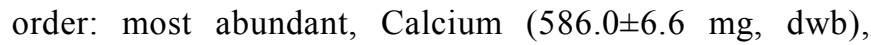
recorded by Abuja sample, East of Gwagwalada market; Potassium (367.0 $\pm 1.4 \mathrm{mg}, \mathrm{dwb})$, documented by Sokoto sample, North of Central market; Magnesium (368.6 33.0 $\mathrm{mg}$, dwb), obtained by Katsina sample, North of Daura market; Phosphorus (295.6 $\pm 3.4 \mathrm{mg}$, dwb), recorded by Sokoto sample, North of Central market; Iron (36.8 \pm 2.8 $\mathrm{mg}$, dwb), obtained by Sokoto sample, East of Central market; Sodium (29.9.9 $\pm 0.5 \mathrm{mg}$, dwb), recorded by Sokoto sample, West of Central market; Manganese (3.8 $\pm 1.4 \mathrm{mg}$, dwb), obtained by Abuja sample, West of

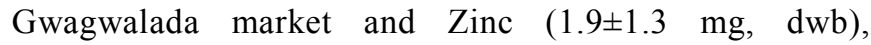
obtained by Sokoto sample, North of Central market.

\section{Recommendations}

Moringa oleifera Lam. plants from the studied locations should be explored for export as an international commodity since its nutrient qualities including Protein, Lipids, carbohydrate/sugars, fibers and mineral contents serve as an 
excellent functional food source for human and animal feedstock, and the content of Potassium $(351.9 \pm 1.3 \mathrm{mg}$ to $367.0 \pm 1.4 \mathrm{mg} \mathrm{dwb})$ compared to Sodium values $(25.9 \pm 0.4-$ $29.9 .9 \pm 0.5 \mathrm{mg}, \mathrm{dwb}$ ) in this study, leads to a very low $\mathrm{Na} / \mathrm{K}$ ratio which is a favorable diet nutritionally, that is associated with lower incidence of hypertension.

\section{Conflict of Interest}

The author declares there is no competing interest.

\section{References}

[1] Osuagwu, OS, RIA Ega, T Okoh and AA Oyerinde. (2014). Comparative studies of the physicochemical properties and mineral elements of Moringa oleifera Lam. leaves in the Guinea Savannah of Nigeria. Inter J Agri Biosci, 3 (6): 266270. www.ijagbio.com

[2] Monica A. Valdez-Solane, Veronica Y. Mejia- Garcia, Alfredo Tellez- Valencia, Guadalupe Garcia-Arenas, Jose SalasPachco, Jose J. Albe- Romero, and Brick Sierra-Campos. (2015). Nutritional Content and Elemental and Phytochemical Analyses of Moringa oleifera Grown in Mexico. Journal of Chemistry, Vol. 2015, Article ID 860381, 9 pages. http://dx.doi.org/10.1155/2015/860381.

[3] Paulsamy S, Jeeshna MV. (2011). Preliminary Phytochemistry and antimicrobial studies of an endangered Medicinal herb Exacum bicolor Roxb. Res. J. Pharm Biol Chem Sci 2011: 2 (4): 447-457.

[4] Yanishlieva, N. V., Marinova, E., Pokorny, J. (2006). Natural antioxidants from herbs and spices. Eur. J. Lipid Sci. Technol. 108. 776-793.

[5] Joshi, P; and Mehta, D. (2010). Effect of dehydration on the nutritive value of drumstick leaves. $J$. of Metabolomics and system biology vol. 1 (1) PP 5-9.

[6] Moyo, B; Masika, P. J; Hugo, A, and Muchenje, V. (2011). Nutritional characterization of Moringa (Moringa oleifera Lam) leaves. African J; of Biotechnology, vol; 10 (60) pp 12925-12933.

[7] Xiaoming, Z; Daniel, M; John, N. A; Arthur, G; Eric, K; and Godelieve, M. (2011). Comparison of Volatile profile of Moringa oleifera leaves from Rwanda and china, using HSSPME. Pakistan J; of nutrition 10 (7): 602-608. (2011).

[8] Miracle Trees, September 2014, http://miracletrees.org/.

[9] Dhakar, R., Pooniya, B., Gupta, M. (2011). "Moringa the herbal gold to combat malnutrition". Chronicles of Young Scientists, Vol. 2. No. 3, pp. 119-125, 2011.

[10] Jung, I. L. (2014). "Soluble extract from Moringa oleifera leaves with a new anticancer activity". PLOS ONE. Vol. 9. No. 4. Arcticle ID e95492, 10 pages. 2014.

[11] Fahey, J. W. (2005). Moringa oleifera: A review of the medical evidence for its nutritional, therapeutic and prophylactic properties. Part 1. Tress for life J; 1: 5-20.

[12] Kasolo, J. N., Bimenya, G. S., Ojok, L., Ochieng, J., OgwalOkeng, J. W. (2010). Phytochemicals and uses of Moringa oleifera leaves in Ugandan rural Communities. J. Med. Plants Res. 4 (2010). 753-757.

[13] Wilhelm L, Suter D, Brusewitz G. (2004). Drying and Dehydration. Food and Process Engineering Technology, St. Joseph, Michigan: ASAE: American Society of Agricultural Engineers.

[14] Karam M, Petit J, Zimmer D, Baudelaire D, Scher J. (2016). Effects of drying and grinding in production of fruit and vegetable powders: A review. J. Food Eng. 188: 32-49.

[15] Food Safety Programme (2002). WHO global strategy for food safety: safer food for better health, Geneva, Switzerland.

[16] Vivas A, Gelaye B, Aboset N, Kumie A, Berhane Y, Williams M. (2010). Knowledge, attitudes, and practices (KAP) of hygiene among school children in Angolela, Ethiopia. J. Prev. Med. Hyg. 51 (2): 73-79.

[17] Beuchat L., Komitopoulou E., Beckers H., Betts R., Bourdichon F., Fanning S., Joosten H., and Ter Kuile B. (2013). Low- water activity foods increased concern as vehicles of foodborne pathogens. J. Food Prot. 76 (1): 150172 .

[18] AOAC (1990). Official Methods of Analysis, Association of Official Analytical Chemist, Rockville, Md, USA, $15^{\text {th }}$ edition, 1990 .

[19] Deymie, B; Mutton, J. L, and Simon, D. (1981). Techniques of Analyses and controls in the food industries. Vol; 4: analyze of food components. Aparia, paris, pp. 490.

[20] Tollier, M; and Robin, J. P. (1979). Adaptation of the Sulphuric orcinol method to automatic proportioning of the neutral total sugars. Ann, Technol; Agric, 28: 1-15.

[21] Merril, A. and Watt, B. K. (1955). Energy values of foods. Basic and derivation. Washington D.C; U.S.A, USDA.

[22] Houba, V. W; walinga, V. V. I, and Lee, V. J. J. (1989). Plant analyzing procedure (Part 7, chapter 23). Department of Soil Science, and Plant Analysis, Wageningen. The Netherlands.

[23] World Health Organization (WHO) (2002). WHO traditional Medicine strategy 2002-2005.

[24] Charles, W. Y; Marcel, D. B. Y; Philippe, A. N; and Sabadenedyo, A. T. (2011). Determination of chemical composition of nutritional values of Moringa oleifera leaves. Pakistan J. of nutrition 10 (3); 264-268.

[25] Thanapat, S; Suchada, J; and Supawan, B. (2010). Nutrients and minerals content of Eleven Different Samples of Moringa oleifera Cultivated in Thailand. J; Health Res. 2010, 24 (3); 123-127.

[26] FAO/WHO. (2002). FAO/WHO. Human vitamin and mineral requirements. Report of a joint FAO/WHO Expert Consultation. Bangkok, Thailand, Rome: World Health Organization and Food and Agricultural Organization of the United Nations, 2002.

[27] Pamplona, R. (2006). Encyclopedia of foods and their Healing power. vol. 1 pp 100-103.

[28] Institute of Medicine (IOM) (2002). Food and Nutrition Board. Dietary reference intakes for Vitamin A, Vitamin K, arsenic, Boron, Chromium, Copper, Iodine, Iron, Manganese, Molybdenum, Nickel, Silicon, Vanadium and Zinc. Washington, DC: National Academy Press, 2002. 